\title{
SOCIAL INNOVATION AND CIVIL SOCIETY \\ ORGANIZATIONS IN ITALY \\ CASE STUDIES ON MENTAL HEALTH AND DISABILITY
}

\author{
INOVAÇÃO SOCIAL E ORGANIZAÇÕES DA SOCIEDADE \\ CIVIL NA ITÁLIA \\ ESTUDOS DE CASO EM QUESTÕES DE SAÚDE MENTAL \\ E DEFICIÊNCIA
}

\author{
Eugenia de Rosa \\ Istat, Istituto Nazionale di statistica, Via Cesare Balbo, 16 Roma, Italia. Email: eugenia.derosa@istat.it
}

\begin{abstract}
Civil society organizations play a vital role in setting the agenda in health and social rights and in the development of innovative public policies. Spending cuts, however, challenge the capacity of civil society organizations to innovate. Utilizing a case-study approach, this paper addresses the role of civil society disability and mental health organizations as social innovators in Italy during the economic crises. The first case-study concerns social housing for people with mental/cognitive impairment. The second, concerns regional legislation for the introduction of Personal Assistance for people with disabilities. This paper shows that civil society organizations continue to have the power to innovate, but are relatively powerless to establish policy priorities at national level.
\end{abstract}

Keywords: civil society organizations, social innovation, mental health, disability.

Resumo: As organizações da sociedade civil desempenham um papel vital na definição da agenda sobre direitos sociais e de saúde e sobre o desenvolvimento de políticas públicas inovadoras. No entanto, os cortes de gastos colocam em causa a capacidade inovadora das organizações da sociedade civil. Mobilizando estudos de caso, este trabalho aborda o papel de organizações da sociedade civil que trabalham com a deficiência e a saúde mental enquanto inovadoras sociais durante a crise económica em Itália. O primeiro estudo de caso diz respeito a habitação social (social housing) para pessoas com deficiência mental. O segundo caso diz respeito à legislação regional para a introdução de assistência pessoal para pessoas com deficiência. Este trabalho mostra que as organizações da sociedade civil continuam a ter o poder de inovar, mas têm pouco poder em estabelecer prioridades políticas a nível nacional.

Palavras-Chave: organizações da sociedade civil, inovação social, saúde mental, deficiência.

\section{Civil society organizations as social innovators in the fields of mental health and disability}

Since the 1960s, civil society organizations (CSOs) ${ }^{1}$ and activists in Europe have a crucial role in defining mental health and disability issues, and in the development of reforms of mental health policies and services (Gardien, 2012). CSOs have played a role both in setting the agenda in the negotiation of meanings of health and social rights, as well as in re-designing policies. They made a fundamental 
contribution by challenging the official definition of disability, which was rooted in the "individualized medical problem" (Oliver \& Barnes, 2012, p. 12). They also contributed to the shift from a restrictive concept of health, focused on rehabilitation, to a broader holistic concept (Barnes \& Bowl, 2001; Barnes \& Prior, 1995; Barnes \& Shardlow, 1996; 1997; Battams \& Johnson, 2009; Hodge, 2005; Percy \& Tirrell, $2004)$ and to the incorporation and increasing relevance of the social dimension (Beresford, 2002; Oliver, 1981; 1996).

In this context, an alternative conceptualization of disability is based on "social barriers or social model perspective" (Oliver \& Barnes, 2012, p. 12). The social model ${ }^{2}$ shifts the emphasis to "disabled people's common experienced of oppression and exclusion and those areas that might be changed by political action and social change" (Oliver \& Barnes, 2012, p. 22). This led to a call for different policy priorities and responses, and for society and local communities to be responsible for recognizing and removing barriers. Thus, health and disability have become a political concern and object of new rhetoric aimed at changing social and power relations (D'Alessio, 2011; Gramsci, 1971).

In more detail, disability organizations have pioneered concepts such as autonomy, choice, empowerment, individualization, user involvement and independent living, which were subsequently set out in the United Nations (UN) Convention on the Rights of Persons with Disabilities (CRPD) adopted in 2006 and implemented in May 2008. According to the UN CRPD people with disabilities are "those who have long-term physical, mental, intellectual or sensory impairments which in interaction with various barriers may hinder their full and effective participation in society on an equal basis with others" $(2006$, p. 3$)$. In this study, disability organizations are understood as CSOs "of people with disability" and mixed organizations "of and for people with disability".

Independent living includes "the opportunity to make choices and decisions regarding where to live, with whom to live and how to live [and] ... having the freedom of choice and control over one's own life and lifestyle" (ENIL, n. d.). In Article 19 the CRPD recognizes the right of people with disabilities to live independently and be included in the community, a right which is underpinned by the general principle of the "full and effective participation and inclusion in society" set out in Article 3.

The underlying philosophy of independent living entails that people with disabilities are able to participate in the community. This requires the provision of services and support inspired by individualization and user involvement to ensure the full inclusion and participation of people with disabilities. Consequently, the concepts of aid and social intervention have to change: "Help is organized on the 
principle that the disabled person should have as much control as possible over the kind of services they receive, how they are organized and delivered, to fit in with the person's own aspirations and preferences" (Mansell, Knapp, Beadle-Brown \& Beecham, 2007, p. 1). This implies the involvement of users in the development and management of services, which is being translated into a growing number of user-led organizations working in the field of disability and mental health and increasing role for users' relatives groups.

The above principles, widely identified by people with disabilities as crucial to their status as equal citizens, have redefined policy domains and introduced a new perspective in the delivery of mental health and disability services. Disability organizations have become agents of change in mental health and disability policies.

Today, most disability organizations are active in both advocacy and service provision (Desse, 2012) in a context characterized by rapid transformation in European welfare states and social policies (Bee \& Guerrina, 2013; Kendall, 2011). The shift from "welfare state" to "welfare mix", the increasing use of contractual principles as regulatory tools (the "new contractualism"; Ramia, 2002, p. 51) and the rising welfare costs has led to new mixed models of delivery, which include spin-outs from the public sector, associations, co-operatives, social enterprises and new welfare partnerships, such as public-private partnerships. In addition, social innovation, understood as a context dependent novelty in action which is usually a "result of collaboration, creativity and a shared goal that is focused towards sustainability and community orientation" (Weerakkody, Sivarajah, Irani \& Osmani, 2014, p. 3) presents increasing relevance.

According to Phills, Deiglmeier and Miller, "to be considered an innovation, a process or outcome must be either more effective or more efficient than preexisting alternatives" (2008, p. 37). Unlike in other services and sectors, in the social policies and social services sector, "the characteristics of novelty, improvement and sustainability have to apply not only to new products (new social services, new form of delivery services) and new ideas (new social work method, new governance, new organizations, new partnerships) but also involve the sphere of social practices and the underlying values of these" (Crepaldi, De Rosa \& Pesce, 2012, p.14).

The capacity of CSOs to innovate policies and service provision in mental health and disability in general, has been called into question by cuts in public spending following the recent economic downturn. The crisis has affected health conditions, participation in society and standards of living for people with disabilities. In fact, several governments in Europe have reassessed disability status, and lowered benefits without consultation of people with disabilities (European 
Disability Forum, n. d.). In this scenario, the paradigm of social innovation promoted by institutions, including European institutions, reinforces the role of third sector organizations in delivering public services. However, as stressed by some authors, the social innovation paradigm can be used to foist the cost of social services onto the third sector, and weaken the capacity of state-third sector partnerships to find more efficient solutions to meet people's needs. In this light, social innovation appears as a functional reaction to market and State failure, revealing its "dark side" (Phills, Deiglmeier \& Miller, 2008) and is thus a controversial issue.

The article is structured as follows. The next section describes the aim of this study and the mobilized methodological approach. Next, this paper overviews the debate on mental health and disability issues and recent developments of the welfare system and social policies in Italy. Following, the experience of innovative social housing programmes for people with mental/cognitive impairment is presented. The next section describes local legislation to introduce personal assistance for people with disabilities in Italy. The final section reports some concluding remarks and identifies future challenges for CSOs in promoting social rights and the health of people with disabilities.

\section{Aim and methodology}

This study focuses on the Italian context and adopts a case study methodology. It aims to investigate the influence of disability civil society organizations on mental health and disability policy-making during the crisis, taking into account recent developments in service provision and CSO-public relations.

Two case studies are presented. They illustrate policy change driven by CSOs and different ways in which CSOs are currently involved in disability and mental health service provision. In addition, these cases further show the impact of austerity politics on the functions of disability organizations.

The first case is a social housing programme for people with mental/cognitive impairment. The second concerns regional legislation for the introduction of personal assistance for people with disabilities. While the first reveals the development of social innovation at an advanced stage, the second presents this development in an early stage.

The selection and analysis of case studies was carried out using the methodological framework developed by the Consortium of the Innoserv project ${ }^{3}$, supplemented with new theoretical elements.

The starting point is a working definition of social and health service innovation where innovation can be found in (a) a new or better service for an 
existing need; (b) an alternative approach for an existing need or new form of delivery; (c) a new service for a new need; (d) a new form of governance, a new form of resourcing, a new way of evaluation; (e) an increased professionalism in service or new managerial methods (Crepaldi, De Rosa \& Pesce, 2012, pp. 106-107; De Rosa, 2012, pp. 34-35;). Innovation should address problems faced by society in changing social relations towards a more inclusive society and should be able to create "public value" (Weerakkody, Sivarajah, Irani \& Osmani, 2014). Furthermore, service innovation has a cognitive and relational content that cannot be measured simply by economic criteria and indicators (Crepaldi, De Rosa \& Pesce, 2012, p. 15).

In both case-studies, criteria used for the selection in this study are: a) the introduction of new social and user-centered approaches to the management of inclusion of people with disabilities; b) the presence of institutional innovation such as a new law or regulatory framework; c) the engagement of user and/or user's relatives' organizations. The selection also reflects specific features of Italy, given that mental health policies and disability policies in general developed independently and are still nowadays distinct fields of action to a certain extent. The first case-study concerns mental health and the second concerns disability. This leads to mention of the ongoing international debate on the development of a social model of mental health and distress to parallel the social model of disability, and on the desirability and possibility of identifying a unified social model of mental health (Beresford, Nettle \& Perring, 2010).

Contextual analysis, relevant legislation and other documentation were carried out for both case studies. For the first case-study, 10 interviews with professionals and service users of residential projects were conducted. Interviews were recorded and data were analysed using the emergent framework to group and compare the data of different case studies within the Innoserv project. We then looked for similarities and differences between practices. Analysis was iterative and progressive. A video was also produced within the Innoserv project to illustrate the innovative practice and take into account the point of view of professionals and service users involved. Visualisation enabled low cost sharing and exchange of practice-based approaches as well as discussions at local level (e.g. with users and practitioners), ensuring their involvement in scientific research. For the second case-study, the analysis is mainly based on grey literature because academic publications on the Italian context are not available. 


\section{Key principles in practice in Italy}

Along with the other Southern countries, Italy shares a Mediterranean system of welfare (Ferrera, 1996) and a family-based model of care (Lewis, 1992). More specifically, family policies and care remain, for the most part, in the private domain of households, and are largely the responsibility of women (Evers \& Laville, 2004, p. 28). In what concerns the third sector, despite its long tradition and growth, its role as a service provider remains limited, still presenting insufficient employees. In 2015, the public health care budget was cut by 2 billion 350 million euros, and such cuts have further exacerbated this scenario in Italy (Barbieri \& Scherer, 2009), with youngsters, women, people with disabilities and migrants being most at risk of social and labor exclusion.

For several reasons, Italy differs from other countries in what regards mental health and disability fields. First, Italy was one of the first European Member States to shift care for people with mental/cognitive impairment from hospital to the community by law, in the Basaglia reform of 1978 (Law n ${ }^{\circ} 180 / 1978$ ). This reform also introduced social-based and empowering policies and an innovative cultural and social approach to psychiatric illness. In addition, the Law $n^{\circ} 180 / 1978$ marked the end of "manicomi" (madhouses) for psychiatric care and the start of a process aimed at creating territorial structures for mental/cognitive impairment, outside hospitals and within communities.

In parallel to the 1978 national psychiatric reform, there were several social-based and empowering initiatives targeted at people with mental/cognitive impairment, largely attempts at residential communities, often managed by "social solidarity cooperatives" (later called "social" cooperatives) (Borzaga \& Santuari, 2001; Fazzi, 2011), and inspired by the independent living principle and the idea of human dignity.

Regarding disability, since the 1970s numerous CSO initiatives have promoted the idea of self-help/mutual aid (Borkman, 1999). This entails small groups of users and/or users' relatives that share their experiences in order to solve problems of participation in society, as well as the ideal of full participation by the people with disabilities in society, including health, social and identity needs. This type of initiative pioneered independent living initiatives and, often, was subsequently managed by social cooperatives, associations or foundations.

Secondly, civic initiatives for people with mental/cognitive impairment and initiatives for rights relating to disability generally started and developed separately, in Italy. For many years, these were distinct phenomena, and they are still today distinct to a certain extent. 
Thirdly, Italy is characterized by a limited implementation of the UN CRPD, especially regarding deinstitutionalization and independent living. Although progress has been made, the implementation of deinstitutionalization continues to present critical issues (Carli \& Paniccia, 2011). These include the wide variation between Italian regions (Malara, 2014), reflecting different territorial welfare models as well as progress towards deinstitutionalization and community living. Currently, the national government in Italy highlights priority targets and interventions for comprehensive local health services and mental health policy, and establishes the essential levels of assistance (LEA). These initiatives aim to guarantee equity of care. The supply of mental health services and interventions are provided by regional and local authorities which are responsible for planning and implementing interventions. The institutional system is based on a definition of mental health service user as psychiatric user according to the 9th International Classification of Diseases (ICD-9-CM) of the World Health Organization.

The implementation of the Law $n^{\circ} 180 / 1978$ was delayed by conservative politicians, and in many cases official psychiatrist and clinical medicine organizations caused obstruction. In addition, recent studies reveal a serious shortage of semi-residential and residential facilities, especially in southern Regions (ibidem). In some areas, management of people with mental/cognitive impairment is an unsolved problem and families continue to bear the brunt.

A further critical issue is the integration of health and social areas and the availability of integrated support services, which affects the field of disability in general. A significant reform was implemented through Law $n^{0} 328 / 2000$, which redefined the local social protection model in Italy and based it on the principles of integration, public-third sector partnership and a holistic conception of the citizen-user. But again, the reform is being implemented differently across Regions and Municipalities in terms of levels of integration between public and private actors and between health and social services, and in terms of disparities in economic resources.

The "First National Programme of Biennal Action for People with Disabilities", developed by the National Observatory on the Condition of People with Disabilities, highlighted the theme of a broad and structural reform of the current Italian system of certification of the condition of disability. However, this programme was found to be obsolete and complex, and to generate inequalities. In fact, it was considered that "The Italian welfare system does not adopt tools to evaluate the disability consistent with the logic of the UN Convention, is of made 'anchored' to a medical and medicolegal vision (invalidity civil) or is still lacking in methodological indications (recognition of handicap and severe handicap) or is 
strongly differentiated and fragmented (regional systems for the evaluation of non-self-sufficiency) with the consequence that the access criteria to services and the recognition of economic benefits tend not to consider the levels of activity and participation appropriately of the person with disability" (2013, p. 8).

Another critical point, clearly showing how most of the UN CRPD is not being applied in real life, is independent living. With the exception of Law $\mathrm{n}^{\circ}$ $162 / 1998$, which mentions independent living, there is no specific law concerning independent living at national level. The amended Article 39 of Law n ${ }^{\circ}$ 104/1992 gave Regional authorities the power to implement indirectly managed ${ }^{4}$ assistance programs, including personalized plans available on request, and monitor services and their effectiveness. Although it had certain limitations, Law 162 was a turning point. It showed a shift in social policy, and also allowed policy experimentation to become more widespread. This occurred for example in Venice, and in Friuli Venetia Giulia and Piedmont regions. In the following years, Italian legislation further emphasized the role of regional authorities 5 in planning, coordination and delivery of healthcare services, including mental health services, and each region set up its own mental health system ${ }^{6}$.

Today, independent living projects exist, but as experimental projects at municipal level, and they are still ancillary to health services, managed at regional level. So, there is a multitude of scenarios. While certain regions have a specific law, in others, national legislation (exclusively guidelines for project management) establishes and governs independent living projects.

\section{Social housing for people with mental/cognitive impairment in Italy}

The first case-study concerns housing and accommodation. The project Residenzialità Leggera ("Light residential project" for people with mental/cognitive impairment) in Milan, run by the Aiutiamoli Foundation, is an example of an innovative service and state-third sector partnership in the context of reduced public spending. It comprises integrated housing, social and health services for mental health rehabilitation and is made possible by multi-level governance. The target group includes people with mental/cognitive impairment who are not able to live autonomously in their homes.

The project began during the 1980s and was set up and designed by an association consisting of users' relatives and professionals. This association subsequently became the Aiutiamoli Foundation. The association aimed to respond to the needs and concerns expressed by relatives of people with mental/cognitive 
impairment. Initially, users were provided with low-rent sheltered accommodation consisting of five bedsits, one occupied by a social worker, located in the outskirts of Milan. This project resulted in two or three patients being able to develop an independent life. However, the social worker left the project, and lack of funding and difficulties in the relationships with local services can account for the project not to be considered as a full success.

In 2008, the project was redesigned thanks to new regional legislation, which reflected a paradigm shift in the mental health sector. Regional Law $\mathrm{n}^{\circ} 6789$ (Lombardy Region, 2004) on "Redevelopment of psychiatric patients' residential accommodation" introduced small-scale basic residential projects to support autonomy for people with mental/cognitive impairment through living outside residential structures. The law allowed for differentiation in community intervention.

Implementation of such individualized programs is based on finding appropriate housing solutions and appropriate forms of social support for the subject concerned. In practical aspects, the "Light residential projects" have been managed by CSOs and private organizations in partnership with public authorities. As determined by the Regional Plan on Mental Health (DGR 17513 of 05/17/2004), an experimental basis was set up including:

- a new type of residential structure called Rehabilitation Psychiatric Community in Medium Protection (CRM);

- "Light residential accommodation" health programs provided by accredited actors to supply housing solutions for resident users. The Regional Plan specifies that housing solutions need to be found preferably within the local network. "This type of accommodation facility will comply with the instructions of the DM 14.01.1997. These new models of residential psychiatric need a phase of monitoring and verification of the organizational and operating procedures" (Lombardy Region, 2004, p. 2).

These residential projects are funded by public authorities, Lombardy Region for the health part and the municipality of Milan for the social part. In this "Light housing", users in groups of three to five live daily life together, share resources and opportunities, and can rely on professional support, in collaboration with community services.

In 2013, when the case study was conducted, the Aiutiamoli Foundation was carrying out two "Residential" projects in a partnership between the public and third sector. The projects were started in June 2010 and renewed in the following 
years. They were a fixed element in regional planning and fully included in public mental health services. It is important to note that the psychiatric budget of the Lombardy Region was not reduced during the crisis.

Specifically, the Foundation offered two types of housing solutions: living in group homes and living alone. The apartments are located in the same building in Molise-Calvairate, a disadvantaged suburb of Milan.

The "Clessidra" project (living in group homes) is also managed by the Aiutiamoli Foundation and is carried out with the Department of Mental Health of the Fatebenefratelli Hospital of Milan. This project provides "Light residential accommodation" for 14 people living in three apartments in the center of Milan.

Moreover, the Foundation has another apartment thanks to the donation of a user's family ("Aquilone project"). In the "Aquilone project" (living alone), the foundation manages five public housing units where eight users can live independently in the outskirts of Milan. Bedsits are considered the most suitable accommodation for users who have difficulty sharing accommodation with other people. These users already have residential experience, and, in some cases, are on the waiting list for subsidized council accommodation. For both the projects, staff and peer support are available. There are two strategies in place to prevent isolation of users: (a) daily visits by a social worker to each apartment; (b) informal weekly meetings between the operational coordinator of the project, the operators on duty and all the users, to discuss both positive and critical aspects. These meetings are held in the different accommodation units in rotation.

The service aims to meet the need of people with mental/cognitive impairment to live independently, either in a shared apartment or in a home. As noted in the FRA Report (2012), living arrangements and support in daily living represent key areas of intervention to ensure a gradual transition to independent living and inclusion in the community for people with mental health issues. The service is a good example of a responsive social action in mental health.

The "Light residential project" represents a new model of integrated residential psychiatric service. Thanks to the presence of two types of expertise, on social rights, related to citizenship rights, and on health, related to rehabilitation, it constitutes a middle ground between purely territorial and purely citizenship aspects. There is also integration between the social and health sectors from the point of view of funding, which is supplied from both. It is also important to stress that innovation emerged from citizen-led initiatives (self-help or mutual aid logic/social care logic, and then multi-stakeholder logic), and was subsequently supported by changes in the framework of local legislation, 
reflecting a paradigm shift in the mental health sector. Associations were able to play a key role as agents of change, reflecting the fact that CSOs have existed for over twenty years in the area, and were solidly rooted in the community. Innovation was possible in a context marked by the start of the process of deinstitutionalization, where new social services were being planned to meet new and unmet needs. The original association became a point of reference in the Milan area, and was able to adapt to the context and the need to raise funds by diversifying their activities, creating a network, and setting up what became the Auitiamoli Foundation.

The Foundation today is still a reference point in Milan and the metropolitan area in the field of mental health. It is part of the organizing committee Mental Health Campaign, a network of more than sixty associations in the region of Lombardy. This type of consolidated network was a key factor in the efficiency of the practice. Associations involved in the "Light residential project" can rely on a vast network of public, private and third sector actors, ASL (Local Health Units), Regional governments, CSV (voluntary civil service groups), various foundations and associations are all involved. The collaboration and coordination of these networks and partnerships concretely yield advantages for users.

The users perspective on housing is another key aspect. The "Light residential service" facilitates a process of autonomy and empowerment for users. In contrast with traditional community intervention for provision of accommodation, "Light residential accommodation" is innovative in that it provides flexible solutions in residential psychiatric care following an individualized approach. When users are invited to take part in the "Light residential project", factors including their different needs and personal histories as well as the type of housing, alone or in a group, are taken into account.

To sum up, the main features of the projects are: (a) the partnership between profit and nonprofit organizations, public, private and third sector organizations (Osborne \& Chew, 2008; Pestoff \& Brandsen, 2009); (b) integration between social service approaches, sectors, professional expertise (health and social sectors) and the combination of different lines of funding. Easy access to housing for people with mental/cognitive impairment is a typical example of the blurring approach. The "Light residential project" is, in fact, integrated with other activities carried out by Aiutiamoli and day centers; (c) rehabilitation; and (d) the knowledge and use by the user of the territory. Other significant aspects are the centrality of the user and active role of the user's relatives and networks.

Despite the effects of the crisis on public spending, this case demonstrates a local example of the involvement of CSOs in service delivery in terms of "particular 
potential of identifying the needs of citizens" (Bode \& Brandsen, 2014, p. 1056), and a more cost-efficient delivery through the integration of more services and lines of funding. If, on one hand, legislation is an enabling factor of welfare innovation, on the other hand, it is at multi-level and requires coordination of various actors in order to avoid "dispersion of resources and often confusion in users or/and too much bureaucracy" (ENIL, 2015, p.1).

The main challenge is to scale up and replicate the experience in other towns and regions in order to meet all the needs of people with mental disabilities.

\section{Main results from interviews}

Interviews with social workers, manager and users of the project "Residenzialità leggera" were carried out in 2013. A video was also produced reporting the experience of those living in the "Aiutiamoli housing"7.

According to operators and social workers, the main obstacle faced by the project was guaranteeing continuity of staff. Instead, from the point of view of the manager "the main challenge for the operators is to balance protection and respect for the freedom of the citizen-user" (Interview, line 15, 2013).

A key success factor, on the other hand, is that "the duration of light residential intervention is flexible and an extension can be requested" (ibidem). However, the manager continued, "the time dimension is very important. Interventions must have timing, including in giving the structure to the user. This also gives more hope in the case of stabilized situations" (ibidem). The manager reported that the service raises the level of awareness and acceptance of mental impairment by young users. In some cases, young people involved in "Light residential projects" have subsequently accepted further help and entered a community. Great attention was paid to the placements. The project manager reports "Patients who already have social relationships and friendships are chosen. Nevertheless, it took time to find effective strategies to make the 5 bedsits communicable" (Interview, line 10, 2013).

Interviews with users revealed that the group, comprising other users and social workers, has a protective and supportive function. A critical point identified by users was anxiety about the future, although they stated that the experience of living independently increases confidence with daily domestic activities and their potentialities. Users stated the "Light residential project" impacted on their capacity to plan for the future, as well as their current health and quality of life. In particular, one user stated he wanted to find a job and have a family (Interview, line 22, 2013). 


\section{Personal assistance for people with disabilities in Italy}

The second example of welfare innovation driven by CSOs, is the introduction by law of the figure of Personal Assistant for people with disabilities, and innovation inspired by the paradigm of independent living.

As set out in Article 19 of the UN CRPD, a Personal Assistant can be distinguished from other types of services by the following characteristics: (a) "the service user is the customer or the boss"; (b) "users have the option to custom-design their own service, which requires that they are able to decide who will work for them, which tasks they will perform, at which times, where and how"; (c) "users are free to choose their preferred degree of personal control over service delivery"; (d) "the funding follows the user, not the provider, and should be set at market level to allow recruitment of assistants on the open labor market, as opposed to among family members"; (e) "for a personal assistance policy to be effective... it needs to be combined with other policies around independent living... there should also be provision for peer support" (ENIL, 2016, pp. 1-2).

Since 1989, European states have implemented in different ways the principles of personal assistance, translating them into a variety of practical solutions. In Italy, the independent movement is fairly recent, like Independent Living Centers. The Italian branch of the European Network on Independent Living (ENIL) was established only in 1991 and in 1996 ENIL-Italy published the Manifesto of Independent Living based on and clarifying the core concepts of this paradigm, including personal assistance.

A national law covering personal assistance and independent living is lacking, and because each region has autonomy in creating its own legislation, the availability of the service depends on the particular municipality. Figure 1 gives an overview of the situation in 2010 in terms of personal assistance, and reveals great differences between municipalities (ENIL, 2015).

With the recent crisis, the government mobilizes the "rhetoric of austerity" and has recently reduced funding for independent living and personal assistance for people with disabilities. There have been heavy cuts in public spending at national level. Since 2009, transfers of money to municipalities to finance social spending have suffered drastic reductions, mainly due to cuts to the National Fund for Social Policy. According to Istat (2016), in 2013 resources allocated by the municipalities to the welfare territorial policies amounted to about 6 billion 800 million euro, of which $24 \%$ was for disability.

Budget constraints are an important factor in reducing the influence of CSOs. According to ENIL, limitations such as the introduction of part payment of costs and 


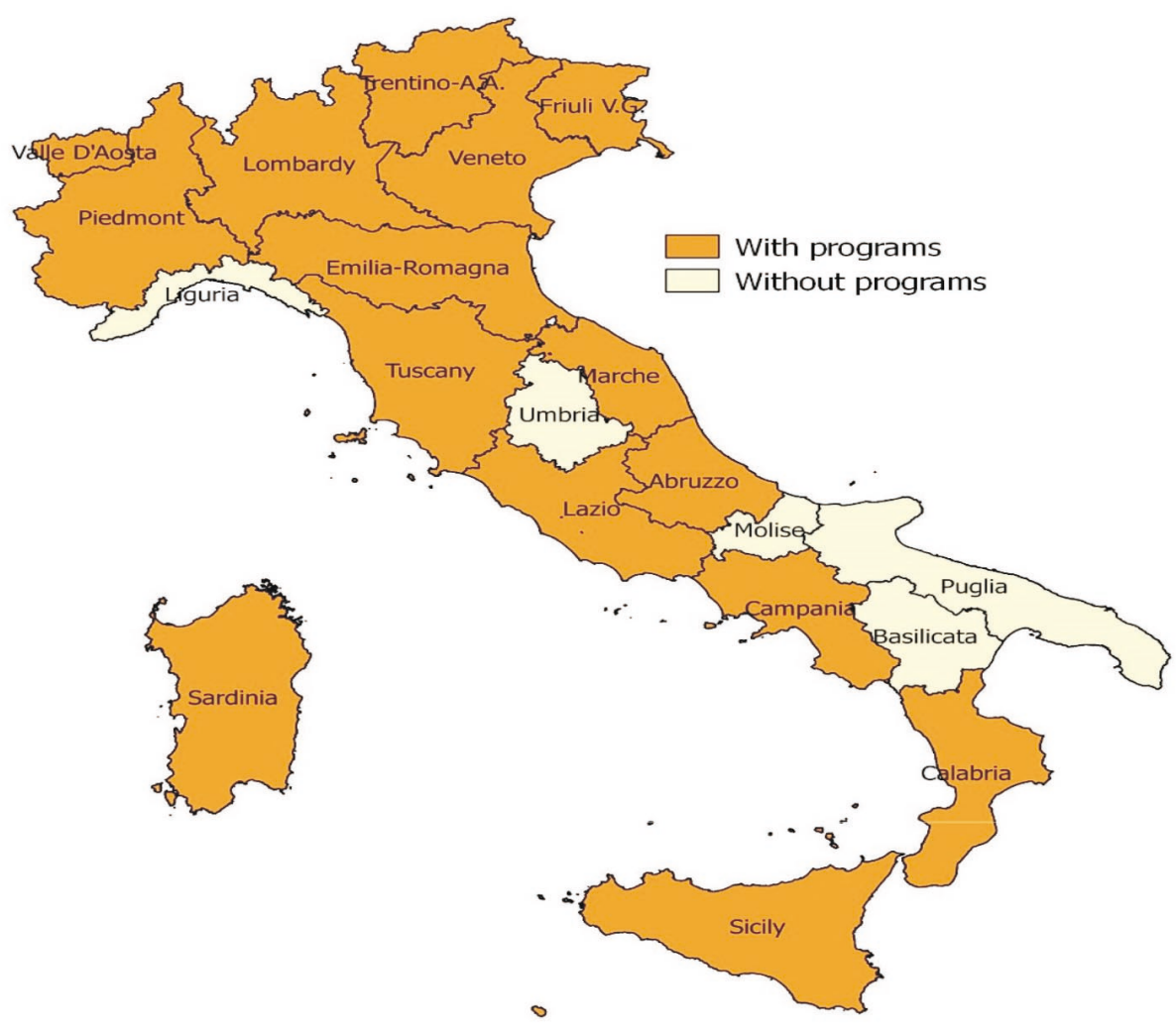

Figure 1 Italian regions with implemented personal assistance programmes (2010)

Note: The Law on Independent Living was approved in Basilicata, but its underlying projects are still not implemented. Source: Consequor, available at http://www.consequor.it/Regione/DelibereAltreRegioni/delibere2.htm; retrieved on 22/01/2018

corruption in the last 5 years have restricted the use of personal assistance: "Politicians support institutions and foundations giving charity type assistance in order to get economic support and/or percentages in earnings" (ENIL, 2015, p. 3). Overall, the number of users has increased in Italy, but funding for each user has decreased. In addition, most local authorities do not have enough resources to cover all individuals who need personal assistance and only part of them receive it (ibidem). According to ENIL (2013), Sardinia has approximately 1000 users of personal assistance programmes, Lazio 400, and exclusively located in Rome, Tuscany 300, of which about 100 users in Florence. Emilia Romagna has 50, Marche 50 and Abruzzo 20 (ibidem, p. 11).

Several local authorities have also taken austerity measures and protests took place. This occurred, for example in the region of Tuscany, where ENIL organized 
a protest against the re-distribution of public resources and put forward the following demands: increased funding for independent living; accounting of costs using self-certification; no payments for social services by people with severe disabilities and close family members, and the use of European structural funds for independent living for people with disabilities (ENIL, n. d.).

In face of the cuts in social services, CSOs were the only actor active in campaigning for legislation and personal assistance services that would underpin the philosophy of independent living with important achievements. In different regions, activists and groups of people with disabilities claimed indirect assistance as a precondition for independent living.

One of the most interesting examples of social innovation in this field is the approval of a Regional law on Independent Living and the introduction of Personal Assistance for people with disabilities in Abruzzo, in 2012, (Regional Law $n^{\circ}$ 57/2012). Disability activists and independent living organizations proposed the law and campaigned for its approval, and Abruzzo became the second Italian Region to have legislation on independent living.

The law states that "independent living means the right of persons with disabilities to self-determination and control of their daily lives and their future. Independent living is achieved primarily through self-managed personal assistance or the assistance of one or more personal assistants" (Regional Law no 57/2012, p. 1). According to the resources available from the regional budget, the Region, at the request of the social agencies identified by the Regional Social Plan, allows the direct implementation of projects of self-managed personal assistance based on to the provision of annual funding. In addition, the law states that "self-managed personal assistance is achieved through the implementation of aid programs, based on custom designed plans, presented annually to appropriate institutions, including those in the municipality where the user resides, and managed by the recipients" (ibidem).

In conclusion, we have seen that CSOs played a key role as agents of change in the first case ("Residential - Light residential projects"). This reflected the fact that CSOs have existed for over twenty years in the area, and have been deeply rooted in the community. Innovation was possible in a context of the start of the process of deinstitutionalization, where social services were being planned to meet new and unmet needs (De Rosa \& Pesce, 2013). Innovation emerged from citizen-led initiatives (self-help or mutual aid logic/social care logic, and then multi-stakeholder logic), but was subsequently supported by changes in the framework of local legislation, reflecting a paradigm shift in the mental health sector. 
CSOs in partnerships with public sector were the driving force of social innovation because they were able to: a) change social relations between individuals, intra-group and between social groups in order to change the "regimes of inequality" (Moulaert, 2009, p. 17); b) meet the needs of deprived and disadvantaged groups of citizens (Moulaert, 2000; Moulaert, 2009); c) guarantee a democratic governance and a civic leadership (Hambleton \& Howard, 2012) in the delivery of public services.

This experience highlights how social innovation may also involve "old ideas" adapted to new contexts and times. "Light residential projects" are more inclusive services than residential structures and comprise integrated social and health intervention, and help a gradual transition to independent living and inclusion in the community. They offer living arrangements outside residential structures and support daily living, as well as social networks with other users and resources of the territory.

The second case-study shows how socially excluded actors can be given voice in negotiations and policy making, and how they can mobilize resources in a context of limited resources and decreasing costs. Informal knowledge of disability organizations and users are key factors in recognizing and utilizing local resources. Users not only contribute to the development and identification of the service but also to the approval of a law that guarantee an innovative service entailing a non-traditional relation between users and assistance.

\section{Future challenges}

Since the 1970s, CSOs and social movements have played a crucial role in defining mental health and disability issues, and have contributed for reforms of mental health policies and services in Italy and around the world. Civil society activism and the involvement of users' relatives have also contributed for the setting up and development of priorities, planning programmes, projects and policies. Activists for mental health and disability rights have also shown that they can create solidarity, promote mutual help schemes and empowerment, and mobilize community resources.

The main challenges for CSOs in the field of mental health and disability have been to change public discourse and influence public opinion and initiate a paradigm shift from a medical to a social model, downplaying stereotypes, and promoting an updated role in society for people with disabilities. These are today consolidated achievements.

In Italy, where disability and mental health policies have tended to develop separately, and are still today, to a certain extent different fields, it is a challenge to 
raise individual user aspirations and expectations of an independent lifestyle, and to favor social inclusion and personalised assistance for people with disabilities, including people with mental/cognitive impairment. In this context, the development of a unified social model of disability, including mental health (Beresford, Nettle \& Perring, 2010), may provide a stronger basis for advocating social rights to integrated and territorial health and social services and benefits, taking into account the European Pillar of Social Rights 8 . But even at national level, it is clearly important for public administration to take responsibility for services and housing solutions for people with mental/cognitive impairment and to ensure equal access across the country.

Greater attention to the social model might also counter the risk of the "privatized" view of individual autonomy as economic independence or participation. In addition, it should contribute to search for new strategies and partnerships with the public sector. This would help to shape and deliver a new generation of innovative user-led and co-produced public services, and avoid the risk for CSOs of marketization and burocratization. The case-studies carried out in Italy show the importance of a tradition of civic initiative and third sector-public partnerships in guaranteeing an active role for CSOs in the development of public policies.

Nevertheless, the effects of the crisis and the prevailing discourse of austerity are severely challenging the capacity of disability and mental health movements and organizations to shape national and European agendas, and the allocation of resources. Budget constraints and deteriorating public finances are pressuring social protection expenditure and welfare services, particularly in the care sector. This may cause a deterioration of the quality of services, while declining levels in funding may weaken the capacity for voluntary and civil society organizations to support people and communities (Reuter, Coudray, Freiberga, Laino \& Rapo, 2014). Overall, we have found that, on one hand, the disability movement continues to have the power to establish what the goals of disability policy should be, but it has been relatively powerless to establish policy priorities at national level and prevent the rolling back of public provision where austerity narratives have taken hold. The two case studies presented here show that to face this challenge, new partnerships between actors and sectors, between different sectors for example, could be important in shaping and delivering a new generation of user-led and co-produced public services even in the context of austerity. We feel that more attention should be paid to new kinds of relationships where profit and non-profit organizations interact in satisfying unmet needs, combining sustainability and community orientation.

These findings should stimulate a debate within the disability and mental health movement on strategies to warrant institutions to adopt participatory 
budgeting and guarantee the role of CSOs as decision-makers themselves. This strategy should probably rely on promoting renewed attention to the social model of disability, combined with a vision of economic and policy intervention. Promoting a social model of disability implies promoting non-standardized intervention targeted at the people with disability and the mobilization of national and local networks of actors in their implementation.

The emergence of "Mad Pride" in Italy, in Turin in $2011^{9}$ is an important development. Mad Studies are in fact important in keeping attention levels high and providing opportunities for "critical discussion of mental health and madness in ways that demonstrates the struggles, oppressions, resistance, agency and perspectives of Mad people to challenge dominant understandings of 'mental illness'" (Castrodale, 2015, p. 3). As noted in Mad matters: A critical reader in Canadian mad studies", Mad Studies can be defined in general terms as a project of inquiry, knowledge production, and political action devoted to the critique and transcendence of psy-centred ways of thinking, behaving, relating, and being" (LeFrançois, Menzies \& Reaume, 2013, p. 13).

The crisis has revealed the weaknesses of neo-liberal model of economic and policy intervention and, at the same time, the strengths of CSOs. Sharing a common vision of an "economy that meets every day needs by providing taken-for-granted services and goods such as care, telecommunications or food" (Bentham, Bowman, de la Cuesta, Engelen, Erturk, Folkman, Froud, Johal, Law, Leaver, Moran \& Williams, 2013), should be at the core of further action in the field of disability and mental health. A new view of spending implies meeting social needs through hybrid partnerships and innovative funding strategies, based on local sustainability and community-orientation. This could provide a counterargument to public and private business models and put the focus on a social planning and development model, following the perspective of social innovation.

Another critical point is the different roles of public sectors with impact on the capacity of CSOs to act as agents of change. The presented case-studies illustrate different strategies used by CSOs to increase the involvement of public sector, which could be particularly useful to guarantee, in the long term, that new issues are included in the policy agenda. The persistent variations between Italian regions, which continue to reflect different levels of progress in the fields of mental health and disability, could be overcome if the public sector takes the role of ensuring consistency of policy, and presents a clear view of the roles and responsibilities of the different actors. Overall, the public sector could be required to re-frame social policy. 


\section{Notes}

The World Bank defines CSOs as "the wide array of non-governmental and not-for-profit organizations that have a presence in public life, expressing the interests and values of their members or others, based on ethical, cultural, political, scientific, religious or philanthropic considerations. CSOs therefore refer to a wide of array of organizations: community groups, non-governmental organizations (NGOs), labor unions, indigenous groups, charitable organizations, faith-based organizations, professional associations, and foundations" (World Bank, n.d.).

2 Because disability does not concern the individual, the term "disabled" implies that people with an impairment are "rendered disabled" by the society where they live, and not that they are born disabled. Although over the years the social model has been criticised (Dewsbury, Clarke, Randall, Rouncefield \& Sommerville, 2004; Gabel \& Peters, 2004), because of the distinction it makes between impairment and disability (Oliver \& Barnes, 2012), it remains a pragmatic starting point for studies on disability. The capability approach is a valid alternative, capabilities are seen as a combination of skills and context and this overcomes the dichotomy individual/society (Burchardt, 2004).

3 The Innoserv project (Innovative Social Services platform Project developed under the 7th Framework Programme for Research) was carried out from 2012 to 2013 by a Consortium of 11 partners (Universities, NGOs, networks of experts). The project included a review of the literature, in 13 languages, which showed current trends and directions of innovation in the social sector in Europe, distinguishing between the fields of welfare, health and education. The literature review identified criteria for identifying innovative practices. A total of 167 innovative practices were selected in different countries. Next, in-depth studies were made and selected innovative practices were investigated using the case study approach. Finally, short videos of innovative practices were made in order to facilitate and guide discussion with local stakeholders, European experts and academics. The final outputs were a research agenda and a platform for practitioners, users, policy makers and scholars in Europe (http://innoserv.philnoug.com; http://siresearch.eu/public-innovation/ project/innoserv).

4 In Italy, "direct assistance" is when public institutions are in charge of care. When the user takes responsibility, this is called "indirect assistance" or "indirect payments".

5 Legislation and guidelines include for instance "National guidelines for mental health" (2 May 2008); “Decree 15 October 2010: National Information System for MH (SISM)" for collecting data from Regions based on individual records (implemented in 2012); "Guidelines for treatment of autism spectrum disorders in children and adolescents - National Institute of Health" (October 2011); “National guidelines in the field of pervasive developmental disorders with special focus on autism spectrum disorders" (November 2012); “National Action Plan for mental health" (January 2013); and "Introductory document on residential facilities for mental health in adults" 
(October 2013).

6 Regional authorities are responsible for providing health care, whereas local government (Municipalities, social-healthcare districts) plan, manage and provide social services. Since the reform of Section V of the Constitution (Constitutional Law of 18 October $2001 \mathrm{~N}^{\circ}$ 3) regional authorities have taken more responsibilities for healthcare and have acquired legislative powers in social assistance.

7 Available at https://www.youtube.com/watch?v=3VrgjebZW-8.

8 A first, preliminary outline of what should become the European Pillar of Social Rights was presented by the European Commission on 8 March 2016. The preliminary outline is divided into the following three main categories: equal opportunities and access to the labour market, fair working conditions and adequate and sustainable social protection.

9 "Torino Mad Pride" is an organization of users/survivors/ex-patients of the mental health system. One of its most important initiatives in September 2014 was setting up a "Linkedin dei matti" (Linkedin for mad people). The site offers two different registration forms, dedicated to those who want to offer or look for a job.

\section{References}

Barbieri, P., \& Scherer, S. (2009). Labour market flexibilisation and its consequences in Italy. European Sociological Review, 25 (6), 677-692. DOI: 10.1093/esr/jcp009

Barnes, M., \& Bowl, R. (2001). Taking over the asylum: Empowerment and mental health. Basingstoke: Palgrave.

Barnes, M., \& Prior, D. (1995). Spoilt for choice? How consumerism can disempower public service users. Public Money and Management, 15 (3), 53-58. DOI: 10.1080/09540969509387882b

Barnes, M., \& Shardlow, P. (1996). Effective consumers and active citizens: Strategies for users influence on service and beyond. Research Policy and Planning, 14 (1), 33-38.

Barnes, M., \& Shardlow, P. (1997). From passive recipient to active citizen: Participation in mental health user groups. Journal of Mental Health, 6 (3), 289-300. DOI: $10.1080 / 09638239718824$

Battams, S., \& Johnson, A. (2009). The influence of service users and NGOs on housing for people with psychiatric disability. Health Sociology Review, 18 (3), 321-334.

Bee, C., \& Guerrina, R. (2013). Participation, dialogue and civic engagement: Understanding the role of organized civil society in promoting active citizenship in the European Union. Journal of Civil Society, 10 (1), 29-50. DOI: 10.1080/17448689.2013.861651

Bentham, J., Bowman, A., de la Cuesta, M., Engelen, E., Erturk, I., Folkman, P., Froud, J., Johal, S., Law, J., Leaver, A., Moran, M., \& Williams, K. (2013). Manifesto for the foundational economy (CRESC working paper $\mathrm{N}^{\mathrm{o}}$ 131). UK: CRESC. Retrieved from https:/ / foundationaleconomycom.files.wordpress.com/2017/01/wp131.pdf 
Beresford, P. (2002). Thinking about 'mental health': Towards a social model. Journal of Mental Health, 11 (6), 581-584. DOI: 10.1080/09638230020023921

Beresford, P., Nettle, M., \& Perring, R. (2010). Towards a social model of madness and distress? Exploring what service users say (Report). York: Joseph Rowntree Foundation.

Bode, I., \& Brandsen, T. (2014). State-third sector partnerships. Public Management Review, 8 (16), 1055-1066. DOI: 10.1080/14719037.2014.957344

Borkman, T. J. (1999). Understanding self-help/mutual aid. Experiential learning in the commons. New Brunswick: Rutgers University Press.

Borzaga, C., \& Santuari, A. (2001). Italy: From traditional co-operatives to innovative social enterprises. In C. Borzaga, \& J. Defourny (Eds.), The emergence of social enterprise (pp. 166-181). London/ New York: Routledge.

Burchardt, T. (2004). Capabilities and disability: The capabilities framework and the social model of disability. Disability and Society, 19 (7), 735-751. DOI: 10.1080/0968759042000284213

Carli, R., \& Paniccia, R. M. (2011). La cultura dei servizi di salute mentale in Italia. Dai malati psichiatrici alla nuova utenza: L'evoluzione della domanda di aiuto e delle dinamiche di rapporto. Milano: Franco Angeli.

Castrodale, M. A. (2015). Mad matters: A critical reader in Canadian mad studies. Scandinavian Journal of Disability Research, 17 (3), 284-286. DOI: 10.1080/15017419.2014.895415

Crepaldi, C., De Rosa E., \& Pesce, F. (2012). Work package 1: Literature review on innovation in social services in Europe (Health, education and welfare sectors of services) (InnoServ report). Retrieved from http://www.dwi.uniheidelberg.de/md/dwi/forschung/innovatio/literature_rev iew.pdf

D'Alessio, S. (2011). Inclusive education in Italy. A critical analysis of the policy of integrazione scolastica. Rotterdam: Sense Publishers.

De Rosa, E. (2012). Innovazione sociale e minority groups. Cooperative sociali e welfare locale nella città di Roma. Sociologia e ricerca sociale, (99), 93-125.

DOI: 10.3280/SR2012-099006

De Rosa, E., \& Pesce, F. (2013). Theoretically informed case study accompanying the film Light Residential Projects - Italy. Italy: INOSERV. Retrieved from http://innoserv.philnoug.com/sites/default/files/IRS_Light\%20Residential_ final_0.pdf

Desse, F. (2012). The role and structure of civil society organizations in national and global governance. Evolution and outlook between now and 2030 (Working paper for WP6). AUGUR Project. Retrieved from http://www.augurproject.eu/IMG/pdf/cso_note_provisional_draft5_june_2012.pdf

Dewsbury, G., Clarke, K., Randall, D., Rouncefield, M., \& Sommerville, I. (2004). The anti-social model of disability. Disability E Society, 19 (2), 145-158.

DOI: $10.1080 / 0968759042000181776$ 
European Disability Forum. (n. d.). Report on the impact of the crisis on the rights of persons with disabilities. Retrieved from

http://www.edf-feph.org/sites/default/files/report-economic-crisis.doc

European Network on Independent Living - ENIL. (n. d.). Italian independent living activists' occupation of the Regional Government gave change. Retrieved from http:/ / enil.eu/news/italians-demonstrate-that-protests-work/

European Network on Independent Living - ENIL. (2013). Personal assistance services in Europe. Retrieved from

http://www.enil.eu/wp-content/uploads/2012/06/European-Survey-on-Persona 1-Assistance-Final.pdf

European Network on Independent Living - ENIL. (2015). Personal assistance survey. Retrieved from http://enil.eu/wp-content/uploads/2013/02/10.-PA-table_Italy.pdf European Network on Independent Living - ENIL. (2016). Fact sheet: Personal assistance. Retrieved from http://enil.eu/wp-content/uploads/2016/06/FAQ_Personal_Assistance.pdf Evers, A., \& Laville, J. L. (Eds). (2004). The third sector in Europe. Cheltenham: Edward Elgar.

Fazzi, L. (2011). Noi welfare. L'innovazione nelle cooperative sociali in Italia. Italia: Euricse/ ConfCooperative. Retrieved from http://www.forumterzosettore.it/multimedia/allegati/Innovazione $\% 20$ nelle $\% 20$ cooperative\%20sociali.pdf

Ferrera, M. (1996). The 'Southern model' of welfare in social Europe. Journal of European Social Policy, 6 (1), 17-37. DOI: 10.1177/095892879600600102

FRA. (2012). Choice and control: The right to independent living. Luxembourg: Publications Office of the European Union.

Gabel, S., \& Peters, S. (2004). Presage of a paradigm shift? Beyond the social model of disability toward resistance theories of disability. Disability and Society, 19 (6), 585-600. DOI: 10.1080/0968759042000252515

Gardien, E. (Ed.). (2012). Des innovations sociales par et pour les personnes en situation de handicap. Toulouse: ÉRES.

Gramsci, A. (1971). Selections from the prison notebooks of Antonio Gramsci. New York: International Publishers.

Hambleton, R., \& Howard, J. (2013). Place-based leadership and public service innovation. Local Government Studies, 39(1), 47-70, DOI: 10.1080/03003930.2012.693076

Hodge, S. (2005). Participation, discourse and power: A case study in service user involvement. Critical Social Policy, 25 (2), 164-179. DOI: 10.1177/0261018305051324

Istat. (2016). Disposizioni in materia di assistenza in favore delle persone affette da disabilità grave prive del sostegno familiare. Audizione del Presidente dell'Istituto nazionale di statistica Giorgio Alleva. Roma: Istat. Retrieved from

https://www.istat.it/it/files/2016/04/A-Audizioni-disabilit\%C3\%A0-5-aprile-20 16_senato.pdf?title=Disposizioni+su+assistenza+a+persone+disabili+-+06\%2Fapr \%2F2016+-+A+-+Audizioni+disabilit\%C3\% A0+5+aprile+2016_senato.pdf 
Kendall, J. (Eds.) (2011). Handbook on third sector policy in Europe. Cheltenham: Edward Elgar.

Law $\mathrm{n}^{\circ} 180 / 1978$. (1978). Accertamenti e trattamenti sanitari obbligatori. Gazzetta Ufficiale. $\mathrm{N}^{\mathrm{o}} 133$ (13-05-1978).

Law n $\mathrm{n}^{\mathrm{1}}$ 104/1992. (1992). Legge-quadro per l'assistenza, l'integrazione sociale e $i$ diritti delle persone handicappate. Gazzetta Ufficiale. N. 39 (17-02-1992).

Law $n^{\circ}$ 162/1998. (1998). Modifiche alla legge 5 febbraio 1992, n. 104, concernenti misure di sostegno in favore di persone con handicap grave. Gazzetta Ufficiale. N. 123. (29-05-1998).

Law $\mathrm{n}^{\mathrm{o}} 328 / 2000$. (2000). Legge quadro per la realizzazione del sistema integrato di interventie servizi sociali. Gazzetta Ufficiale. N. 265. (13-11-2000).

LeFrançois, B. A., Menzies, R., \& Reaume, G. (Eds.) (2013). Mad matters: A critical reader in Canadian mad studies. Toronto: Canadian Scholar's Press.

Lewis, J. (1992). Gender and the development of welfare regimes. Journal of European Social Policy, 3, 159-73.

Lombardy Region. (2004). Piano regionale triennale per la salute mentale in attuazione del piano socio sanitario regionale 2002-2004. Retrieved from https:/ / polser.files.wordpress.com/2011/11/prsm2004.pdf

Malara, P. (2014). Mental health in Italy regulatory system and addressing documents with special focus on child and adolescent. Power point presentation at Youth Mental Health: from continuity of Psychopathology to continuity of care, Venice, December 2014.

Mansell, J., Knapp, M., Beadle-Brown, J., \& Beecham, J. (2007). Deinstitutionalisation and community living. Outcomes and costs: Report of a European study (Volume 2: Main report). Canterbury: Tizard Centre, University of Kent.

Moulaert, F. (2000). Globalization and integrated area development in European cities. Oxford: Oxford University Press.

Moulaert, F. (2009). Social innovation: Institutionally embedded, territorially (re)produced. In D. MacCallum, F. Moulaert, J. Hillier, \& S. Vicari Haddock (Eds.), Social innovation and territorial development (pp. 11-23). Farnham UK and Burlington USA: Ashgate.

National Observatory on the Condition of People with Disabilities. (2013). First national programme of biennal action for people with disabilities [Primo programma di azione biennale per la promozione dei diritti e l'integrazione delle persone con disabilità]. Retrieved from http://www.osservatoriodisabilita.it/images/documenti/programma_d_azione.pdf

Oliver, M. (1981). A new model of the social work role in relation to disability. In J. Campling (Ed.), The handicapped person: A new perspective for social workers (pp. 19-32). London: RADAR.

Oliver, M. (1996). Understanding disability: From theory to practice. Basingstoke: Palgrave Macmillan. 
Oliver, M., \& Barnes, C. (2012). The new politics of disablement. Basingstoke: Palgrave Macmillan.

Osborne, S., \& Chew, C. (2008). The innovative capacity of voluntary organizations and the provision of public services: A longitudinal approach. Public Management Review, 10 (1), 51-70. DOI: 10.1080/14719030701763187

Percy, C., \& Tirrell, I. (2004). User empowerment in mental health services: Towards a more robust definition of empowerment activity. Paper presented at the 3rd International Conference of the International Society for Equity in Health, Durban, South Africa.

Pestoff, V., \& Brandsen, T. (2009). Public governance and the third sector: Opportunities for co-production and innovation?. In S. Osborne (Ed.), The new public governance? New perspectives on the theory and practice of public governance (pp. 223-236). London/New York: Routledge.

Phills, J. A., Deiglmeier, K., \& Miller, D.T. (2008). Rediscovering social innovation. Stanford Social Innovation Review, 6 (4), 35-42.

Ramia, G. (2002). The 'new contractualism', social protection and the Yeatman thesis. Journal of Sociology, 1 (38), 49-68. DOI: 10.1177/144078302128756471

Regional Law $\mathrm{n}^{\circ}$ 57/2012. (2012). Interventi regionali per la vita indipendente. Consiglio regionale dell' Abruzzo. No 57 (23-11-2012).

Reuter, C. (Ed.), Coudray, S., Freiberga, K., Laino, E., \& Rapo, N. (2014). Social progress watch 2014. Belgium: Solidar. Retrieved from http:/ / issuu.com/solidar_eu/docs/country_studies_web

$\mathrm{UN}$. (2006). Convention on the rights of persons with a disability (CRPD). Retrieved from http://www.enil.eu/elib/app/webroot/files/UNconvoptproten.pdf

Weerakkody, V., Sivarajah, U., Irani, Z., \& Osmani, M. (2014). Evaluating the public value of social innovation. Brunei Business School Research Papers.

World Bank. (n. d.). Defining civil society. Retrieved from http://go.worldbank.org/4CE7W046K00

Video

INNOSERV. (2013). Light residential project [Video]. Italy: INNOSERV. Retrieved from http://innoserv.philnoug.com/residential or https:/ / www.youtube.com/watch?v=3VrgjebZW-8

Data de submissão: 13/12/2017 | Data de aceitação: 22/02/2018 